\title{
ADDITIONS TO THE BIRD LIST OF MANITOBA (1997-2007)
}

RUDOLF F. KOES, 135 Rossmere Crescent, Winnipeg MB R2K 0G1

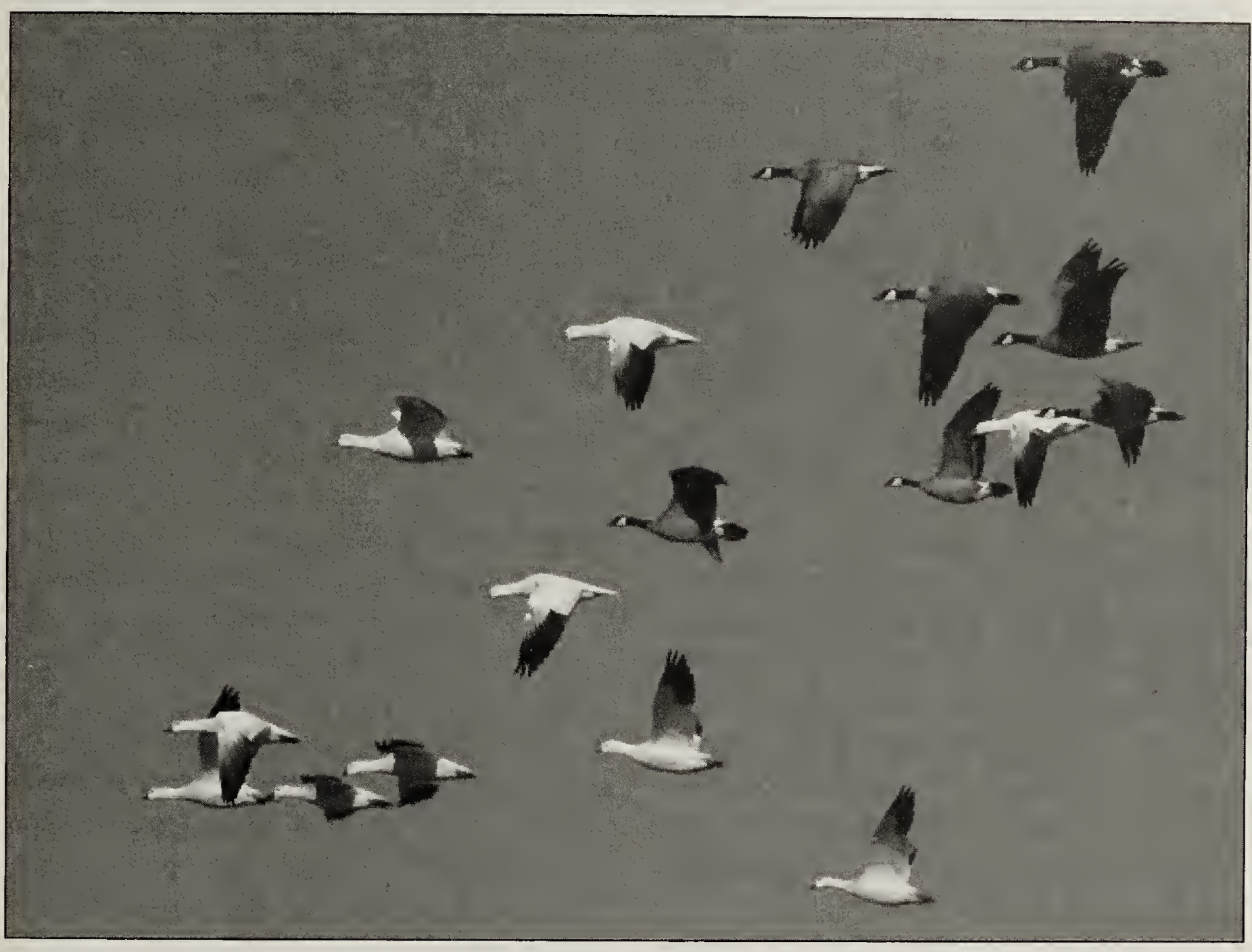

Figure 1. Cackling Geese and Ross's Geese near the Lac du Bonnet sewage lagoon, 19 September 2007.

Peter Taylor

More than a decade has passed since the last article in a series on bird species new to Manitoba appeared in Blue Jay. ${ }^{9}$ In this compilation, additions to the Manitoba bird list from 1997 to 2007 will be discussed. Given that bird populations are never static, with some ranges contracting and others expanding, new species are expected to show up at times while others disappear from our area. Furthermore, with the advent of the Internet, communication between observers has increased tremendously, particularly in the last ten years, which has led to timely reporting and confirmation of sightings of rarities. In

addition, digital photography has allowed birders to document and share such sightings more easily. It is therefore no wonder that Manitoba's bird list has grown considerably since 1996 and stands currently at 389 species, including the 12 listed as confirmed in this article.

Two of the new species added since the last compilation were the result of taxonomic splitting (Cackling Goose and Spotted Towhee) and two were previously on Manitoba's hypothetical list (Black-tailed Gull and Prothonotary Warbler). Two species were added to the hypothetical list (Tufted Duck and 
Bar-tailed Godwit). A few exotics (e.g. Eurasian Siskin and European Goldfinch) merit a brief mention.

The records herein were reviewed by the Manitoba Ornithological Records Committee (MORC) (H.W.R. Copland, Chair; A. Courcelles, R.F. Koes, R.W. Nero, and P. Taylor). Confirmed records (indicated by an asterisk*) are those for which a specimen, photograph, or sound recording exists, or they pertain to well-documented sight records by two or more competent observers. Unconfirmed sightings were convincingly documented by single, experienced observers. All other sightings are considered hypothetical.

${ }^{*}$ Cackling Goose. (Figures $1 \& 2$ ) In 2004 the various races of the Canada Goose complex were split into two species, with the larger birds retaining the Canada Goose name and the smaller ones (with the exception of Lesser Canada Goose) becoming Cackling Goose. ${ }^{2}$ Although very similar in appearance to Canada Geese, Cackling Geese have been shown by DNA studies to be more closely related to Barnacle Geese..$^{31,33}$ In Manitoba, the most common of the four races now included in the Cackling Goose complex is the one which was formerly often called Richardson's Goose. Although it largely breeds in the High Arctic, nesting is also known to occur in the extreme north of Manitoba (M. Gillespie, Manitoba Conservation, pers. comm., 9 November 2006). It is a common to abundant migrant through southern Manitoba, particularly in the southwest, where in fall up to $85 \%$ of checked birds in hunters' bags are Cackling Geese or small Canada Geese. $^{28}$ Some recent counts by birders include 3000 tallied by a Manitoba Naturalists Society outing at Whitewater Lake (in southwestern
Manitoba) on 2 October 2004 and $3000+$ near Warren on $22-23$ April 2008 and 1000 at Lac du Bonnet on 6 8 October 2002, both by Peter Taylor. Migration peaks in southeastern Manitoba are late April to early May and late September to early October, with numbers varying from year to year.

There are very few summer records from the south: one remained through the season in 2007 (and possibly also in 2006) with Canada Geese near Pierson. Similarly, winter records are scarce so far, but expected to increase with continued scrutiny of goose flocks in that season. One lingered, with Canada Geese, until at least 2 January 2006 on the Assiniboine River at Winnipeg ${ }^{25}$ and another was reported on 12 December 2007 at Seven Sisters Falls. Much still remains to be learned about the status of this species in the province.

Tufted Duck. A male was reported near Flin Flon on 19 May 2004. Unfortunately, no details of this sighting have been forwarded to MORC, hence its inclusion on the hypothetical list. ${ }^{20}$

The Tufted Duck, a Eurasian relative of scaup and Ring-necked Duck, occurs annually in small but increasing numbers in both Alaska and Newfoundland, with vagrants ranging farther south, primarily along both coasts but also inland at the Great Lakes. ${ }^{35}$ There are scattered records through central U.S.A. and single reports from Alberta and Saskatchewan. ${ }^{30,36,40}$ Given that sightings in continental North America have increased more than tenfold since the 1960s, future occurrences are expected in the prairie provinces. ${ }^{35,40}$ Hybrids (Tufted Duck $x$ scaup) are frequent, so observers should be extra careful with identification. 


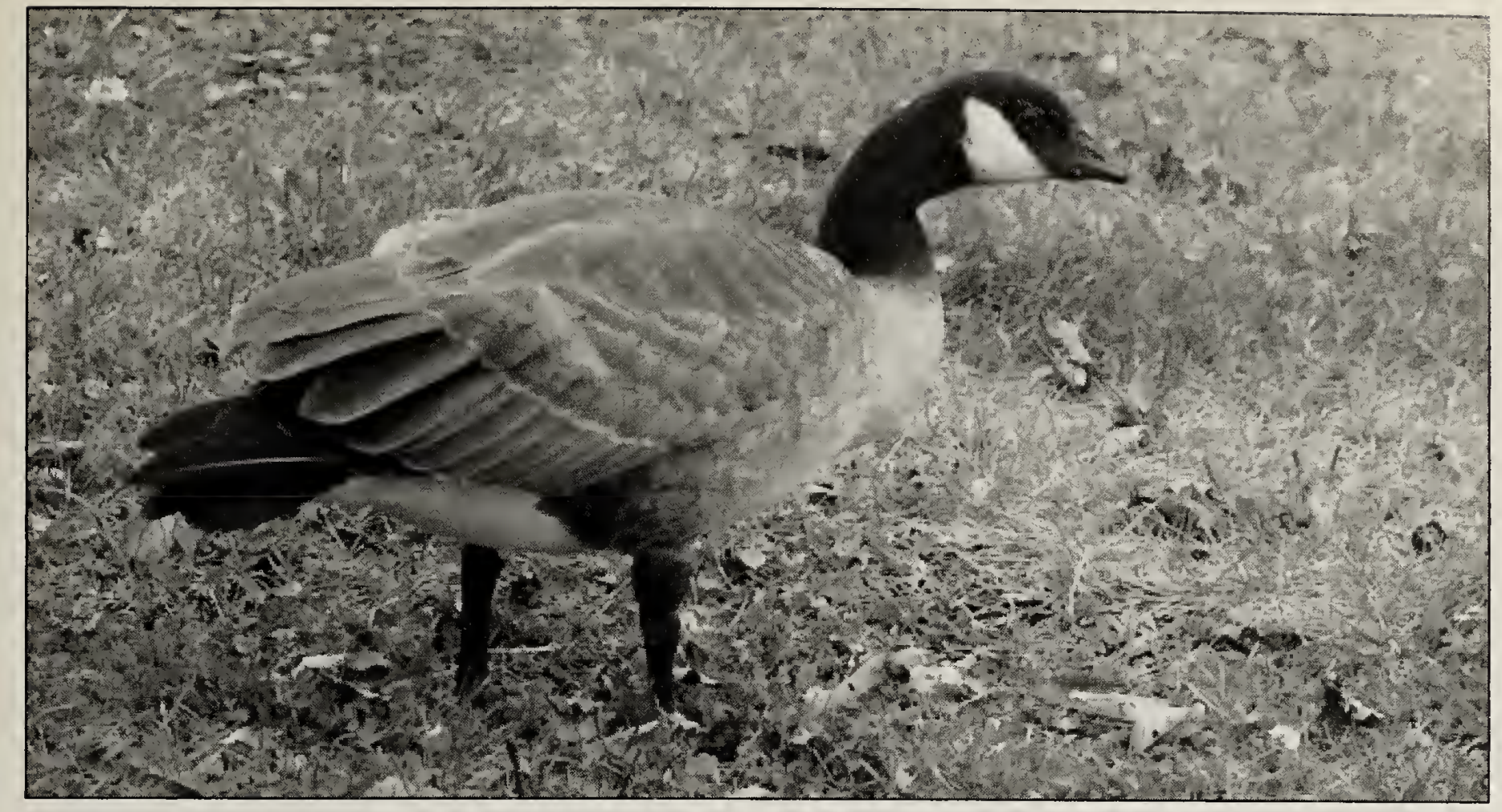

Figure 2. Cackling Goose in late September 2007 at Rainbow Falls, Manitoba

Deanna Dodgson

(Note: On 23 April 2008 a male Tufted Duck was seen and photographed by Nia Massey as it briefly visited the Red River behind her home, between Selkirk and Breezy Point. The photographs are diagnostic and there is no doubt that the record will be accepted by MORC in the near future).

*Wood Stork. Manitoba's birding community learned, months after the fact, that a juvenal Wood Stork had been seen and photographed by visiting birders between the community of St. Ambroise and St. Ambroise Provincial Park, near the southeast corner of Lake Manitoba, on 5 August 2005. The observers were Norbert Riezing, who also photographed the bird, and Timea Gaspar, of Hungary. ${ }^{24}$

The nearest breeding areas are in southeastern U.S.A., but the species is known to wander widely, so its occurrence in Manitoba was not entirely unexpected.

*Black Vulture. The occurrence of a Black Vulture at Wanless, in centralwestern Manitoba, on 11 May 2006 has previously been described in detail in
Blue Jay by Christian Artuso. ${ }^{3}$ This species wanders frequently north of its breeding range: there are numerous records for Ontario and recent sightings in Minnesota, plus outlying reports from Saskatchewan and Yukon. ${ }^{3,5}$

Bar-tailed Godwit. Birders who have visited Churchill in recent years are no doubt aware of the Rare Bird Alert board erected at Akudlik, outside of town. Sightings of rarities are usually recorded on it, and as such it serves a valuable purpose. In June 1998, two Bar-tailed Godwits were recorded on the board as having been seen along the Churchill River near town, on the 25th and again on the 27th, by one (or more?) members of a tour group. To the author's knowledge, no others present in Churchill at the time managed to locate the birds. Unfortunately, no details have come to light since, including the name(s) of the observer(s). ${ }^{12}$ Confusion with Hudsonian Godwit, a local breeder, is a distinct possibility.

This primarily Eurasian species breeds also in extreme western Alaska, with vagrants occurring along both the 
Pacific and Atlantic coasts of North America. There are no confirmed records for the prairie provinces.

Sharp-tailed Sandpiper. This species has long been on the to-beexpected list in Manitoba, as it is a regular, albeit rare migrant in Alberta and British Columbia.

On 4 June 2000, two visiting birders reported what they believed was an adult in nonbreeding plumage at Oak Hammock Marsh. Other birders present at virtually the same time saw what was presumably the same bird and identified it as a White-rumped Sandpiper. Based on this probable misidentification, the sighting was considered hypothetical. On 22 August 2003, Adam Walleyn observed a juvenile near Gillam and took detailed, convincing notes. ${ }^{19}$ Unfortunately, Walleyn did not have camera equipment with him to document the sighting and no others saw this bird. Then, on 30 August 2005, Robert Storms and Michael Harrison, experienced birders visiting from
Alberta, located a juvenile at Oak Hammock Marsh. ${ }^{24}$ This bird was not located afterwards by others. MORC is still hoping to receive more detailed information on this sighting.

*Black-tailed Gull. (Figure 3) Churchill is known amongst birders as a great place to see gulls, including such sought-after species as Ross's, Little and Sabine's gulls. At last count, 20 species have been recorded here, tying it with the Niagara region of Ontario/New York as the area with the greatest variety of gulls in the world. Number twenty came in the form of an immature (likely second year) Blacktailed Gull seen by Bonnie Chartier and Jeffrey Gordon on 29 June 2006. The bird was documented with excellent photographs and other details by Gordon. ${ }^{26}$

There was one previous record, documented by a single observer: Richard Knapton saw an adult while conducting surveys on Sagemace Bay, at the southwest corner of Lake Winnipegosis, on 2 June $19877^{7,8}$

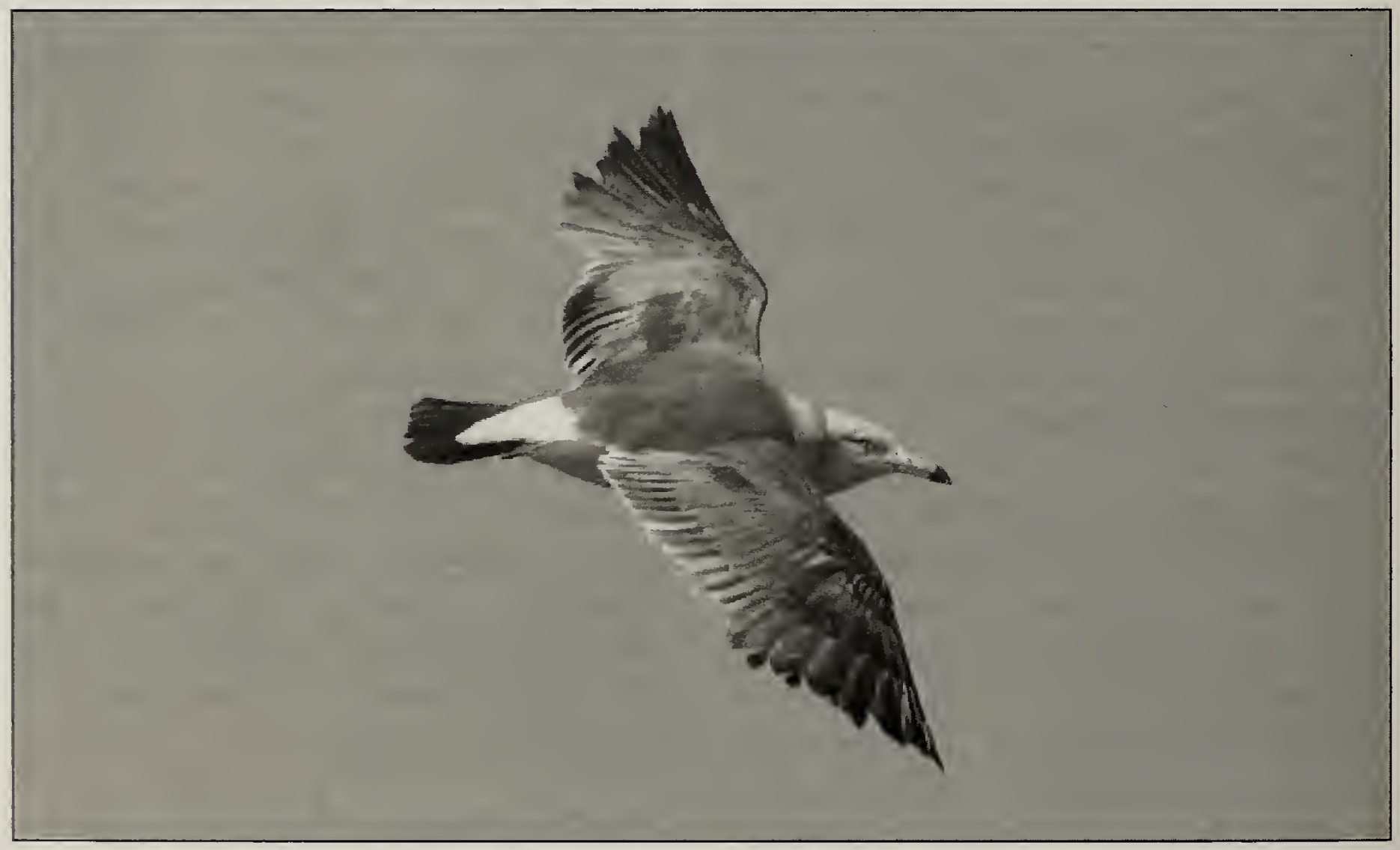

Figure 3. Black-tailed Gull at Cape Merry, Churchill, 29 June 2006

Jeffrey A. Gordon 
Black-tailed Gull is an east-Asian species which is being reported with increasing frequency in Alaska and along the East Coast of North America. ${ }^{35}$

*Slaty-backed Gull. The Portage la Prairie landfill, located between St. Ambroise and Delta and better known amongst birders as the "PR 227 dump", is one of the few productive gullwatching dumps that is still open to the public. ${ }^{29}$ Indeed, birders are made to feel welcome here. While visiting the dump on 11 May 2002, Dennis and Frieda Fast noticed an unfamiliar darkbacked gull. Dennis, a well-known photographer, lacked his usual camera equipment, but Frieda reminded him of the video camera they carried with them and the bird was duly recorded. Later frame-by-frame analysis revealed that the bird was a near-adult Slatybacked Gull. ${ }^{17}$

This is another east-Asian species that has become a regular visitor to the West Coast, with scattered sightings elsewhere in North America, including several in Alberta and Saskatchewan. ${ }^{30}$
${ }^{*}$ Eurasian Collared-Dove. (Figure 4) This species was introduced to the Bahamas in the 1970 s, spread to Florida in the early 1980s, and has since rapidly invaded much of North America. A similar, rapid spread took place in Western Europe in the mid$20^{\text {th }}$ Century. Although it is still local, and far from common, it has become established in all three prairie provinces, with highest numbers so far in Saskatchewan.

A scruffy individual, lacking tail feathers, was video-taped at Winnipeg on 7 January 2000 and was likely the first Collared-Dove for the province, but the images were not entirely diagnostic. ${ }^{14}$ One cooperative bird at Holland, present for about a week up to 12 May 2003, provided the first confirmed record. First noted by Colleen Steinke and then identified by Adam Walleyn, it was seen and photographed by many. ${ }^{18,28}$ Another individual was seen at Landmark on 18 and 19 October 2003. During fall 2004 and winter 2004-2005 up to two birds were near Pierson, in the extreme southwest of Manitoba, and a probable

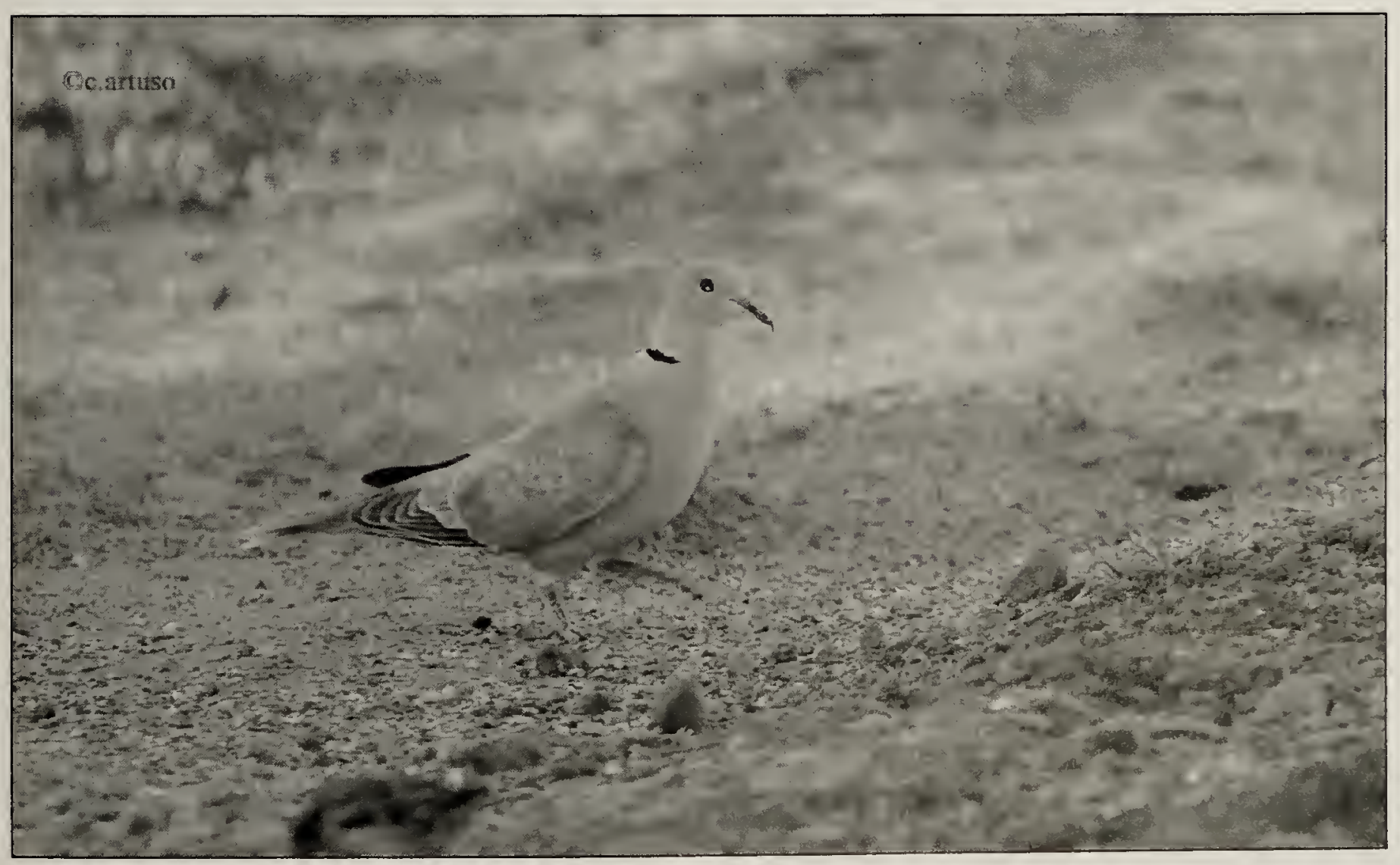

Figure 4. Eurasian Collared-Dove at Lyleton, MB, 2 June 2007 Christian Artuso 
Eurasian Collared-Dove was at the Brandon Hills. In May 2005 (and again in 2006 and 2007) the species was found nesting at Lyleton, not far from Pierson. ${ }^{23}$

Other reports have come from Dauphin, MacDonald, Winkler and Winnipeg. At the Winkler location, up to 10 birds were present during the fall of 2007 (Leonard Braun, pers. comm.). No doubt this dove will continue to spread slowly across southern Manitoba.

*Broad-tailed Hummingbird. (Figure 5 on the inside front cover, top) Were it not for the loud whistling sound created by its wings in flight, an out-of-range Broad-tailed Hummingbird could easily be dismissed as a Ruby-throated Hummingbird. Fortunately, Carrie and Helen Braden noticed this characteristic sound when a hummer showed up at Helen's feeder near Portage la Prairie on 16 May 2006. The bird was tentatively identified as a male Broad-tailed Hummingbird at the time; this was soon confirmed by others. The hummer was last noted on 29 May, after it had been seen and photographed by numerous people. ${ }^{3}$ As an aside, this same feeder hosted a Rufous Hummingbird from 15 to 22 September 2004. ${ }^{21}$

The normal range of the Broad-tailed Hummingbird is in the western mountains, from Mexico as far north as central Wyoming, southwestern Montana and probably southwestern South Dakota. ${ }^{37}$

Ash-throated Flycatcher. On 18 September 2001, and again two days later, Ken Gardner observed an Ashthroated Flycatcher at Grosse Isle. ${ }^{16,28}$ This southwestern flycatcher had long been on the list of birds expected to appear in Manitoba, as it is a frequent wanderer, with numerous records along the East Coast. No others managed to confirm this sighting and no photographs were obtained.

*Pinyon Jay. On 25 October 2000, a Pinyon Jay was noted at three St. Adolphe feeders. ${ }^{15}$ No photographs were obtained and subsequent searches were unsuccessful, but descriptions provided by observers at two of the feeders were diagnostic. During the same fall there was "a very large movement of various western mountain species out of the mountains" which included Pinyon Jays and was possibly related to particularly widespread fires in western U.S.A. that summer and early fall. ${ }^{27}$

${ }^{*}$ Curve-billed Thrasher. In mid-March 1999, the Manitoba birding community learned of a Curve-billed Thrasher that had been visiting two feeders in St. Claude, apparently since early November 1998. It had been tentatively identified by Raymond Chattel and the identification was confirmed by Heidi den Haan. Dozens of birders descended upon the area on 21 March 1999 to observe and photograph the thrasher, which was last seen on 4 April. ${ }^{10}$ Concurrently, a Curve-billed Thrasher was present in Barrhead, Alberta. ${ }^{10}$ These two sightings represented the first confirmed records for Canada. Recently Saskatchewan added the species to its list when a bird frequented a feeder at Dalmeny from early November until midDecember 2006. ${ }^{32}$

The normal range of this thrasher stretches from Mexico north to Colorado and Kansas.

*Prothonotary Warbler. On 3 October 1997, Andy Courcelles 
discovered a female or immature male Prothonotary Warbler skulking through weeds along a creek bed next to his St. Adolphe home. The warbler remained in the area until 6 October and was seen by many. Detailed descriptions were received by MORC. ${ }^{28}$ Prior to this sighting, there had been two reports: one at Delta on 17 May 1989 and one at Birch Point on Lake of the Woods on 31 July 1990, but neither was documented in detail. ${ }^{9}$ The first photographic evidence was obtained on 12 May 2001 in the form of a videotape taken at King's Park, Winnipeg, by Robyn and Todd Underwood. ${ }^{41}$ Other well-documented sightings have since taken place at St. Ambroise Provincial Park on 11 September 2004 and at Fort Whyte Centre (FortWhyte Alive) from 3 to 6 May 2006. ${ }^{3,21}$

*Swainson's Warbler. Perhaps the most unusual of several outstanding rarities in the spring of 2006 was a Swainson's Warbler seen and photographed on 8 May by Christian Artuso at Beaudry Provincial Park, just west of Winnipeg. It represented the first record for western Canada of this rare denizen of damp woods in the southeastern United States. ${ }^{3}$

*Spotted Towhee. Until 1995, Spotted Towhee was considered to be the western race of Rufous-sided Towhee. ${ }^{1}$ In that year, the complex was "split" (the eastern counterpart became Eastern Towhee). It appears that the first record for the province involved a male collected at Whitewater Lake on 4 May $1925 .{ }^{38}$ Few observers kept track of the form in the following decades, but there are infrequent reports from the 1930 s through the 1980 s. ${ }^{6,39}$ Since the early 1990s, the number of reports has increased, but this is likely due to better communication between birders, rather than a real increase in numbers. Notable recent out-of-range sightings occurred at Churchill on 25 June 1992 and at Winnipeg during the winter of 2004-2005, 11,22 A photograph was taken by Renee Will near Brandon on 7 September 1992. ${ }^{28}$

The first confirmed record after the split involved a male on territory from 4 July 1999 until at least 10 July 1999 near Lauder. ${ }^{13,28}$ (The species was also reported at this location in 2000, 2001 and possibly 2002). At present, a few are noted annually somewhere in the province. Overlap between the breeding ranges of Spotted and Eastern Towhees occurs in southwest Manitoba, southeast Saskatchewan and elsewhere on the Great Plains; this frequently leads to hybridization, so care should be taken when identifying the species. ${ }^{34}$ Mixed pairs have been noted in southwest Manitoba; a male Spotted Towhee paired with a female Eastern Towhee was at Oak Lake in 2007 and there were probably one or two similar pairs in the region in recent years (Ken De Smet, pers. comm.).

Exotics. Accidental or intentional releases of captive birds take place frequently, particularly in the case of waterfowl, doves, parrots and their relatives, and certain small, colourful songbirds. When such a species is seen in the wild, it may brighten up a birding day, but a dilemma arises: Can I count it or not? MORC has taken a conservative approach in its evaluation of sightings involving such species, including Eurasian Siskin and European Goldfinch, both of which have been seen and documented by photographs in recent years. A male Eurasian Siskin (Figure 6 the on the inside front cover, bottom) frequented a Winnipeg feeder in March $2005^{23}$ and European Goldfinches were noted at 
Gimli on 31 October $2003^{19}$ and at St. Adolphe on 10 May 2005..$^{23}$ There is also a second-hand, undocumented, report of a Linnet sighting at Churchill in June 2007 (B. Chartier, pers. comm.).

Rumour has it that a large importer of birds at Vernon Hills, IL, closed shop in 2002 and released most of the birds it kept, which included tits, finches, siskins and linnets. A rash of sightings occurred thereafter, stretching from the Midwest to southern Canada and beyond. While true vagrancy in some of these species is not impossible, it is the less-likely scenario. ${ }^{4}$

\section{Acknowledgements}

Thanks are due to all observers involved in the sightings mentioned in this article, particularly those who took the time to document their sightings. This article benefited greatly from comments and corrections made by Peter Taylor. A thank-you goes also to Christian Artuso, Larry de March, Jeffrey Gordon, Brian Huebert, Peter Taylor and Deanna Dodgson for allowing the use of their photographs.

1. AMERICAN ORNITHOLOGISTS' UNION. 1995. Fortieth supplement to the American Ornithologists' Union check-list of North American birds. Auk 112: 819-830.

\section{AMERICAN ORNITHOLOGISTS' UNION. 2004.}

Forty-fifth supplement to the American Ornithologists' Union check-list of North American birds. Auk 121: 985-995.

3. ARTUSO, C. 2006. Manitoba's southern bird invasion. Blue Jay 64(4): 191- 195.

4. DINSMORE, S.J., and W.R. SILCOCK. 2004. The Changing Seasons: Expansions. North American Birds 58(4): 324-330.

5. HOOPER, R.R. 1993. Possible Saskatchewan sighting of Black Vulture. Blue Jay 51(2): 105

6. KNAPTON, R.W. 1979. Birds of the Gainsborough-Lyleton Region (Saskatchewan and Manitoba). Special Publication No. 10, Saskatchewan Natural History Society, Regina, SK.
7. KNAPTON, R.W. 1990. Black-tailed Gull in southern Manitoba. Blue Jay 48(1): 37-38.

8. KOES, R.F. 1991. Additions to the Manitoba bird list (1985- 1990). Blue Jay 49(4): 202-207.

9. KOES, R.F. 1997. Additions to the Manitoba bird list (1991-1996). Blue Jay 55(2): 97-101.

10. KOES, R.F. 1999. Curve-billed Thrasher winters in St. Claude, Manitoba. Blue Jay 57(2): 75-77.

11. KOES, R.F., and P. TAYLOR. 1992. Prairie Provinces Region. American Birds 46(5):1148.

12. KOES, R.F., and P. TAYLOR. 1998. Prairie Provinces Region. Field Notes 52(4): 468.

13. KOES, R.F., and P. TAYLOR. 1999. Prairie Provinces Region. North American Birds 53(4): 400.

14. KOES, R.F., and P. TAYLOR. 2000. Prairie Provinces. North American Birds 54(2): 191.

15. KOES, R.F., and P. TAYLOR. 2001. Prairie Provinces. North American Birds 55(1): 67.

16. KOES, R.F., and P. TAYLOR. 2002. Prairie Provinces. North American Birds 56(1): 65.

17. KOES, R.F., and P. TAYLOR. 2002. Prairie Provinces. North American Birds 56(3): 318.

18. KOES, R.F., and P. TAYLOR. 2003. Prairie Provinces. North American Birds 57(3): 363.

19. KOES, R.F., and P. TAYLOR. 2004. Prairie Provinces. North American Birds 58(1): 93-94.

20. KOES, R.F., and P. TAYLOR. 2004. Prairie Provinces. North American Birds 58(3): 389.

21. KOES, R.F., and P. TAYLOR. 2005. Prairie Provinces. North American Birds 59(1): 99.

22. KOES, R.F., and P. TAYLOR. 2005. Prairie Provinces. North American Birds 59(2): 284.

23. KOES, R.F., and P. TAYLOR. 2005. Prairie Provinces. North American Birds 59(3): 452-453+ 530.

24. KOES, R.F., and P. TAYLOR. 2006. Prairie Provinces. North American Birds 60(1): 91-92.

25. KOES, R.F., and P. TAYLOR. 2006. Prairie Provinces. North American Birds 60(2): 248.

26. KOES, R.F., and P. TAYLOR. 2007. Prairie Provinces. North American Birds. 60(4): 542+598. 
27. LEUKERING, T. 2001. Changing Seasons, Fall 2000. North American Birds 55(1): 13-19.

28. MANITOBA AVIAN RESEARCH COMMITTEE. 2003. The Birds of Manitoba. Manitoba Naturalists Society, Winnipeg, MB

29. MANITOBA AVIAN RESEARCH COMMITTEE. 2006. Finding Birds in Southern Manitoba. Manitoba Naturalists Society, Winnipeg, MB and Brandon Naturalists Society, Brandon, MB.

30. NATURE SASKATCHEWAN. 2008. Field Checklist of Saskatchewan Birds. Nature Saskatchewan, Regina, SK.

31. RUSCH, D.H. et al. 1994. Biology and management of Canada Geese. In: Proceedings of the 1991 International Canada Goose Symposium, Milwaukee, WI.

32. SAUNDERS, N. and S. SHADICK. 2006. Curve-billed Thrasher at feeder in Dalmeny, SK. Blue Jay 64(4): 218-219.

33. SCRIBNER, K.T., et al. 2003. Phylogeography of Canada Geese (Branta canadensis) in Western North America. Auk 120: 889-907.

34. SIBLEY, C.G., and D.A. WEST. 1959. Hybridization in the Rufous-sided Towhee of the Great Plains. Auk 76: 326-338.
35. SIBLEY, D.A. 2000. National Audubon Society The Sibley Guide to Birds. Alfred A. Knopf, Inc. New York and Random House of Canada Toronto.

36. SLATER, A. undated. Third report of the Alberta Bird Records Committee. Alberta Naturalist 31:1.

37. SOUTH DAKOTA ORNITHOLOGISTS' UNION. 1991. The Birds of South Dakota, 2nd Edition. South Dakota Ornithologists' Union, Aberdeen, SD.

38. TAVERNER, P.A. 1927. Some recent Canadian records. Auk 44: 217-228.

39. TAYLOR, P. 1985. Wings Along the Winnipeg: the Birds of the Pinawa-Lac du Bonnet Region, Manitoba. Revised edition. Eco Series No. 2, Manitoba Naturalists Society, Winnipeg, MB.

40. TOOCHIN, M. 1998. Possible anywhere: Tufted Duck. Birding XXX (5): 370-383.

41. UNDERWOOD, R.M., and T.J. UNDERWOOD. 2001. Prothonotary Warbler in Winnipeg, Manitoba. Blue Jay 59(4): 193-195.

\title{
ADAPTATION: KANGAROO RAT
}

\author{
A xeric rat is thus described: \\ "bipedal, saltatory," \\ which means it hops on its hind legs \\ across the desert story- \\ metabolism's water's all \\ it "drinks," and that's its glory.
}

\section{- Victor C. Friesen}

